\title{
Long-term changes in the seasonality of selected diatoms related to grazers and environmental conditions
}

\author{
Merja H. Schlüter ${ }^{a, *}$, Alexandra Kraberg ${ }^{b}$, Karen H. Wiltshire ${ }^{b}$ \\ a Helmholtz-Zentrum Geesthacht, Institute of Coastal Research, Max-Planck-Str. 1, 21502 Geesthacht, Germany \\ b Biologische Anstalt Helgoland, Alfred Wegener Institute for Polar and Marine Research, P.O. Box 180, 27483 Helgoland, Germany
}

\section{A R T I C L E I N F O}

Article history:

Received 6 December 2010

Received in revised form 24 October 2011

Accepted 2 November 2011

Available online 12 November 2011

\section{Keywords:}

Odontella aurita

Thalassionema nitzschioides

Guinardia delicatula

Climate Change

Seasonal Succession

Helgoland Roads

\begin{abstract}
A B S T R A C T
The decoupling of trophic interactions could be one of the severe consequences of climate warming in aquatic systems. The timing of phytoplankton blooms, in particular, can affect competition within the plankton community as well as food-web interactions with zooplankton and fish. Using long-term data from Helgoland Roads in the southern North Sea, we examine diatom seasonality, using three representative diatom species combined with environmental and copepod time series over the last four decades. The long-term annual abundances of Guinardia delicatula, Thalassionema nitzschioides and Odontella aurita exhibited interannual variations and dissimilar cyclic patterns during the time period under study (1962-2008). Of the three diatoms, G. delicatula showed a significant trend towards earlier bloom timings for 1962-2008 and a later decline of its abundance over time was found. Grazing and water transparency explained most of the bloom timing fluctuations of the diatoms considered. The annual timing of occurrences of each diatom species was correlated with their preceding concentrations. Earlier bloom timings occurred when autumn/winter concentrations were higher than average and later bloom timings occurred when autumn/winter concentrations were lower than average. Different environmental and predation variables related to the diatom bloom timings were found suggesting that climate warming might not affect the onset of the blooms of the three diatom species in the same manner. The results of the multiple linear regression analyses showed that the timings of decline of the three diatoms were mainly correlated with decreasing nutrient concentrations. Sunshine duration could prolong the duration of the blooms of $T$. nitzschioides and 0 . aurita provided that enough nutrients were available. In the case of G. delicatula, however, sunshine duration was negatively correlated with its end of the growth period. G. delicatula and T. nitzschioides showed later decreases in abundances under warmer spring and summer temperatures. Such species specific differences in the sensitivity to the forcing variables could lead to shifts in community structure and could ultimately have wider implications to the overall ecosystem health of the North Sea.
\end{abstract}

(c) 2011 Elsevier B.V. All rights reserved.

\section{Introduction}

Global warming is reality and the warming rate has been far greater in the last decades than it was for the past 10,000 years (IPCC, 2007). Despite the availability of detailed information on temperature changes, there is still only limited information on the effects of a warming climate on aquatic food-webs (Cushing, 1995; Walther et al., 2002; Wiltshire et al., 2008, 2010).

Terrestrial plant responses to global warming have included poleward and altitudinal extensions of geographic species ranges (Thuiller, 2007) and shifts in seasonal activity and growth patterns (Cleland et al., 2007). Analogously to earlier blooming observed in terrestrial plants, various studies concerning marine phytoplankton reported earlier seasonal succession of different species in connection

\footnotetext{
* Corresponding author at: Department of Bioclimatology, University of Göttingen, Büsgenweg 2, 37077 Göttingen, Germany.

E-mail address: mschlue@gwdg.de (M.H. Schlüter).
}

to climate warming (Edwards and Richardson, 2004; Schlüter et al., 2008). Species replacements in zooplankton (Hays et al., 2005; Möllmann et al., 2000) and variation in phytoplankton communities (Jassby et al., 1990; Müller-Navarra et al., 1997) have also been linked to warming. However, Wiltshire and Manly (2004) found retarding or fairly constant diatom spring blooms in the German Bight over the last decades in addition to large interannual variations in the timing of the spring bloom (Wiltshire et al., 2008). Both Wiltshire et al. (2008) and Schlüter et al. (2008) found that diatoms based on average spring and annual abundances were resilient to shifts in temperature. Thus, if other organisms are less resilient to warming (e.g. zooplankton) decoupling of trophic interactions may have severe consequences for the entire food-web (Beaugrand et al., 2003; Cushing, 1990).

Most of the known factors determining phytoplankton succession relate to changes in nutrient concentrations, light (Reynolds, 2006), thermal stratification and predator-prey relationships (Beninca et al., 2008; Reynolds, 1989; Sommer, 1989). In addition, plankton communities 
follow distinct seasonal succession patterns caused by changes in lifehistory traits (Litchman and Klausmeier, 2008; Sommer et al., 1986) and nutrient stoichiometry (Philippart and Cadee, 2000). Responses to climate variability, and the effects of the conditions preceding the spring bloom in temperate shelf seas, have not been well characterised on a species level mainly due to the lack of sufficiently detailed data.

Phytoplankton succession can be influenced by light quality and quantity. The light climate in the coastal water column is related to turbidity and this in turn is related to turbulence/stratification processes (Schrum, 2010). Additionally, the winter water conditions and environment (e.g. temperature, salinity, grazers) may affect the survival rate of micro algal cells and determine the inoculum of species into the spring water, and thus, can determine the succession patterns, e.g. Colijn and Cadee (2003). Only a few studies have so far addressed the impact of climate change, i.e. changes in abiotic conditions such as temperature, light, nutrients, etc., on biotic interactions such as the long-term development of predator-prey relationships in natural marine pelagic systems, e.g. Wiltshire et al. (2008), owing to the complexity of multiple drivers. Wiltshire and Manly (2004) found a delay in the spring bloom at Helgoland Roads and postulated that this was related to increased grazing in winter. A recent modelling study by Gaedke et al. (2009) confirmed that this was possible and showed how changes in temperature may alter grazing of zooplankton thus delaying phytoplankton blooms.

Because the timing of phytoplankton blooms has an impact on food-web interactions with zooplankton and may ultimately affect fish, changes in the phenology of individual species and the variables determining such variations must be taken into account if we are to understand how marine ecosystems respond to increasing temperature (see Greve et al., 2005). There is a need to analyse the responses of individual species particularly to seasonal changes in environmental conditions and to grazing pressure.

This study investigated how variations in long-term environmental conditions and in grazing pressure preceding the bloom affect the bloom timings of three common spring/early summer diatom species observed at the Helgoland Roads time series station $\left(54^{\circ} 11^{\prime} 3^{\prime \prime} \mathrm{N}\right.$, $7^{\circ} 54^{\prime} 0^{\prime \prime} \mathrm{E}$ ) in the German Bight. The variables which potentially affect the end of the bloom pattern were also determined. The Helgoland Roads data are temporally one of the most extensive data sets available in marine systems. This data set holds plankton variables identified to species level along with abiotic variables with a daily resolution.

\section{Data and methods}

\subsection{Study site}

The position of the estuaries of the main rivers (Elbe, Ems, Rhine, Weser) that drain into the southern North Sea coastal waters, along with the counterclockwise residual current pattern which carries river-borne substances from the west to east, favours the accumulation of nutrients from industrial effluents, agricultural runoff, and municipal sewage in the German Bight, although this input has decreased in the last 15 years (Raabe and Wiltshire, 2008). The sampling site nearby the offshore island Helgoland is located about $60 \mathrm{~km}$ northwest of the Elbe river estuary. The Helgoland Roads site is shallow (from 6 to $12 \mathrm{~m}$ ) compared to the surrounding German Bight (mean depths of $30 \mathrm{~m}$ ), and is well mixed. Tidal currents and winds determine the circulation and vertical mixing of coastal and open water around Helgoland.

\subsection{Data sets}

Since 1962, dissolved inorganic nutrients $\left(\mathrm{NO}_{2}, \mathrm{NO}_{3}, \mathrm{NH}_{4}\right.$ and $\mathrm{PO}_{4}$ ), plankton stocks and hydrographical parameters have been measured by the Biologische Anstalt Helgoland (BAH) at Helgoland Roads (HR) site $\left(54^{\circ} 11^{\prime} 3^{\prime \prime} \mathrm{N}, 7^{\circ} 54^{\prime} 0^{\prime \prime} \mathrm{E}\right)$ between the two islands of
Helgoland. Measurements of silicate concentrations $\left(\mathrm{SiO}_{4}\right)$ started in 1966. Temperature, phytoplankton and nutrients were determined on every work-day (Franke et al., 2004), and zooplankton samples were taken three times a week from 1975 to 2005 (Greve et al., 2004). Secchi disc depth has been measured since 1968 . The analysing methods and quality control of the water samples were described in detail in Greve et al. (2004), Raabe and Wiltshire (2008), and Wiltshire and Dürselen (2004).

The diatom data set used in the multiple statistical analyses contained three representative (in terms of relative abundance and annual presence) winter/spring and spring/summer species. The three species chosen were Guinardia delicatula, Thalassionema nitzschioides and Odontella aurita. These three algae were chosen because they co-occur in the data set, making it more likely to see shifts relative to one another. A widening of the time period of occurrence of G. delicatula was also observed (Wiltshire et al., 2010). Experimental work has shown that they have very different temperature growth optima (Schwaderer, 2006). O. aurita (Lyngbye) is a centric marine micro algae (10-95 $\mu \mathrm{m}$ in diameter) previously known as Biddulphia aurita. It is considered a neritic, littoral species by Hendey (1964), a tychoplegic diatom by Drebes (1974) and a cold meso-eurytherm, cosmopolitan species by Baars (1979). It is often found in long chains in coastal waters and acts as an attachment "platform" for other diatoms (Tiffany and Lange, 2002). G. delicatula (Cleve) Hasle is a centric diatom (Drebes, 1974), requires low Si:N ratios compared to other diatoms (Rousseau et al., 2002), and, especially in summer, is one of the prominent primary producers in the phytoplankton of the German Bight. G. delicatula (9-22 $\mu \mathrm{m}$ in diameter) was previously known as Rhizosolenia delicatula. The pennate diatom T. nitzschioides (Grunow) Grunow ex Hustedt is a eurythermal species (Karentz and Smayda, 1984) and is a typical species for neritic waters and mostly associated with mid-latitude pelagic warm waters $(2-4 \mu \mathrm{m}$ diameter, $10-100 \mu \mathrm{m}$ length). It is well adapted to mixing of the water column and high nutrient concentrations. T. nitzschioides has an elongate shape and a high surface area-to-volume ratio which may explain its anomalously high Si:N biomass ratios (Brzezinski, 2004). The predator data used in this paper consisted of the abundances of five small calanoid copepods (Paracalanus parvus, Pseudocalanus elongatus, Centropages spp., Acartia spp., Temora longicornis) which are the main herbivorous grazers on diatoms at the start of the year, see also Greve et al. (2004). These copepods are considered to play a key role in the transfer of phytoplankton carbon to higher trophic levels (Gowen et al., 1999). Beside the limitations due to the hydrographic environment as described by Hickel (1998) and Radach (1998) the extreme regularity, length and satisfactory data quality of the Helgoland Roads time series allow the detection of even weak long-term overall trends (Wirtz and Wiltshire, 2005).

\subsection{Statistical analysis}

To smooth the data a Gaussian filter over time was applied to all raw data for subsequent analyses. Prior to statistical analyses, all plankton samples were log-transformed to normalise the distributions, while still preserving the relative differences in magnitude of occurrence.

To evaluate potential phenological changes in the diatoms, two biological temporal indices after Schlüter et al. (2010) and similar to the approach of Greve et al. (2005) were defined. These were the "Start Of Growth Period" (SOGP) representative for the beginning of the pelagic seasonal cycle, associated with the level corresponding to $15 \%$ of the annual cumulative abundance, and the "End Of Growth Period" (EOGP), associated with the level corresponding to $85 \%$ of the annual cumulative abundance. The difference between EOGP and SOGP was defined as the growth period (GP), see Fig. 1. SOGP and EOGP were assessed for linear temporal trends prior to use in statistical analysis by taking a least squares fit of the data against time. Temporal trends were evaluated 
at the $5 \%$ significance level with a standard Student's $t$-test of the estimated slope parameter.

The explaining variables used for the SOGP of 0 . aurita, T. nitzschioides and G. delicatula were the mean values prior to the bloom timings. In this procedure, nutrients were neglected as forcing factors since severe nutrient depletion did not occur during that period (Loebl et al., 2009). For the EOGP nutrient depletion was relevant. Here, the predicting variables used for the EOGP were the mean values during the growth period.

All the time series were normalised prior to analysis by subtracting the yearly mean abundance from the values and then dividing by their standard deviation. The SOGP indices of the diatoms were separated into three categories corresponding to later, average, and earlier SOGP: i.e. later SOGP values ( $>1$ above the deviation from the 1975-2005 mean value), average values ( \pm 1 around the deviation from the 1975-2005 mean value) and earlier SOGP values ( $<1$ below the deviation from the 1975-2005 mean value). The mean explaining environmental and predation variables corresponding to later, average, and earlier SOGP values of the three diatoms were determined.

In order to evaluate underlying parameters for the temporal indices of the three diatoms $G$. delicatula, $T$. nitzschioides and 0 . aurita Pearson correlation and multiple linear regression analysis were
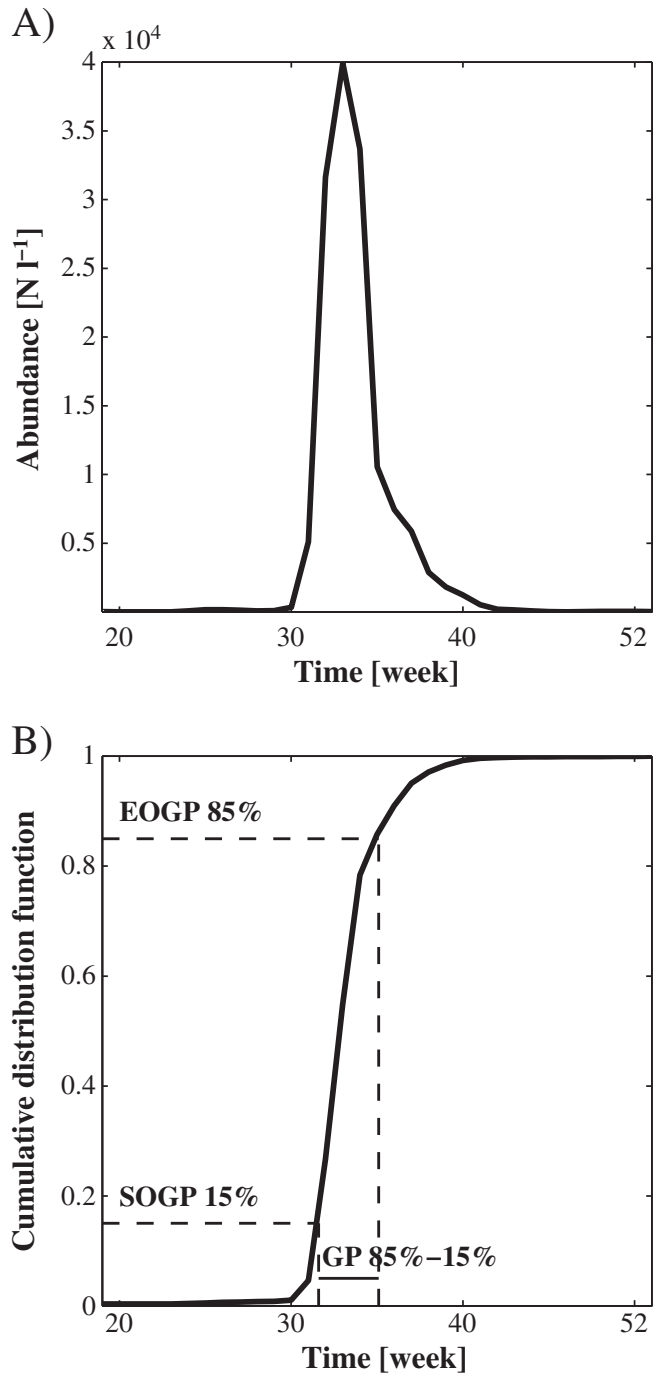

Fig. 1. a) One annual weekly mean abundance of Guinardia delicatula and b) the cumulative distribution function of the annual weekly mean abundances with its "bloom" indices: Start Of Growth Period (SOGP), Growth Duration (GD), and End Of Growth Period (EOGP). performed for possible relationships between the biological temporal indices, the environmental variables and grazing organisms. For analysis including the zooplankton variables the data from before 1975 had to be omitted because the zooplankton data were regularly sampled only from 1975. For multiple regression modelling, data were first assessed for multi-co-linearity and normality (KolmogorovSmirnov test) and transformed where necessary. Subsequently a multiple regression on each diatom index was performed using all possible predictors. The best-fitting model was selected using a backward stepwise procedure. Parameters were assessed at the $5 \%$ significance level by a Student's $t$-test. Robustness of the resulting models $(p<0.05)$ was assessed by testing the residuals for normality (Kolmogorov-Smirnov test) and homoscedasticity (scrutinising plots of normalised residuals). The Durbin-Watson (DW) statistic was used to assess residuals for first-order autocorrelation. To quantitatively ascertain that the results were significant a re-sampling bootstrap test on the $R^{2} \mathrm{~S}$ of the results was used. This technique involves choosing random samples with replacement from the biological indices and regress each sample with the same predictors. All significant analyses conformed to these regression assumptions. Normalised regression coefficients were used to infer the relative importance of model variables for explaining variations in the diatom indices.

\section{Results}

Among the three diatom species $G$. delicatula was numerically the most abundant species over the total time period considered (maximum about $15 \log$ (cells per litre)). This species occurred at various times throughout the year (Fig. 2 a) with highest cell concentrations recorded in early summer and autumn and with lowest cell concentrations recorded during the period from December through February. From 1962 to 1978 G. delicatula was nearly absent during spring, reappearing in April 1978, and reaching its annual maximum in month May (Fig. 2 a). G. delicatula's mean annual values were characterized by annual fluctuations (Fig. 3 a) and it attained high mean annual population densities after 1997 except in 2005 (Fig. 3 a). This species attained its highest population densities in 1980 (5.4 annual mean $\log$ (cells per litre)). 1982 to 1997 was a period of low abundance (2-4 annual mean $\log$ (cells per litre)), followed by another year of high population densities in 1999 (5.6 annual mean log(cells per litre)). From 1999 onwards, this species remained at relatively high yearly mean abundance levels (Fig. 3 a).

T. nitzschioides was the second most abundant species of the three and, with 0 . aurita representing the most important species of the winter and spring phytoplankton assemblages at Helgoland Roads (Fig. 2 b and c). Although $T$. nitzschioides and $O$. aurita occurred each year between January and April, their patterns of yearly abundance were dissimilar. T. nitzschioides' yearly pattern of maximal occurrence was bimodal; cell densities were highest during late winter-early spring and late summer-autumn, and lowest from June to and including August (Fig. 2 b). T. nitzschioides exhibited wide annual fluctuations and peak levels ( 6 mean annual cells per litre log-transformed) occurred at 12-year intervals (Fig. 3 b), as inferred from spectral analysis. $T$. nitzschioides was absent from the phytoplankton assemblage in 1964. 0 . aurita, the least abundant species of the three, occurred each year between January and April (Fig. 2 c), showed a 6-year data cycle and exhibited its highest annual mean abundances during the early 1960s (2.7 annual mean log(cells per litre)). From 1967 onwards, cell densities have been persistently lower than the preceding years (Fig. 3 c). O. aurita was completely absent in the phytoplankton in the years 1988, 1989 and 1995.

For the time period from 1962 to 2008 a trend towards earlier bloom timings was found for G. delicatula and of T. nitzschioides at the $5 \%$ significance level. $T$. nitzschioides also showed a significant trend towards earlier timings of decline in abundance during that time period. Evidence of a trend towards later decline of abundance 
A) G. delicatula

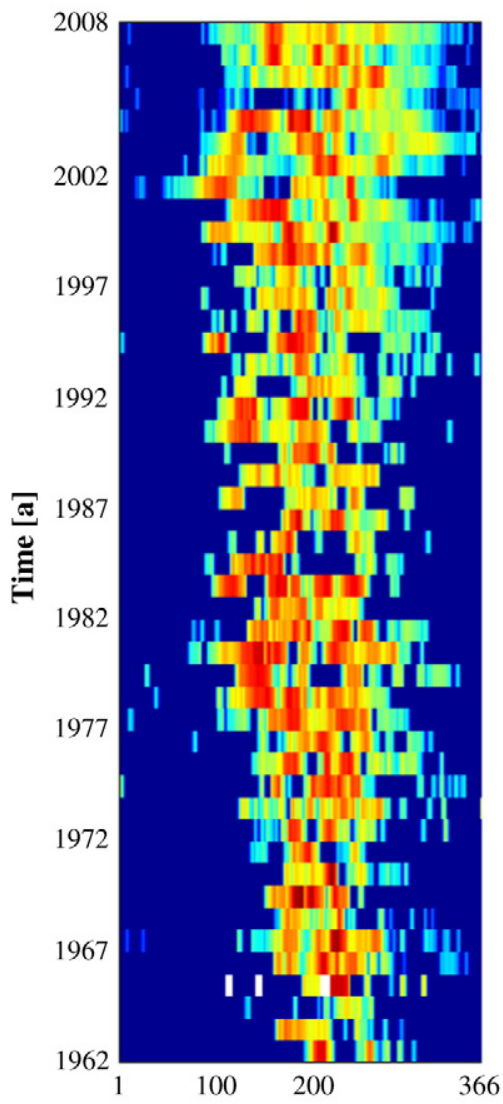

B) T. nitzschioides

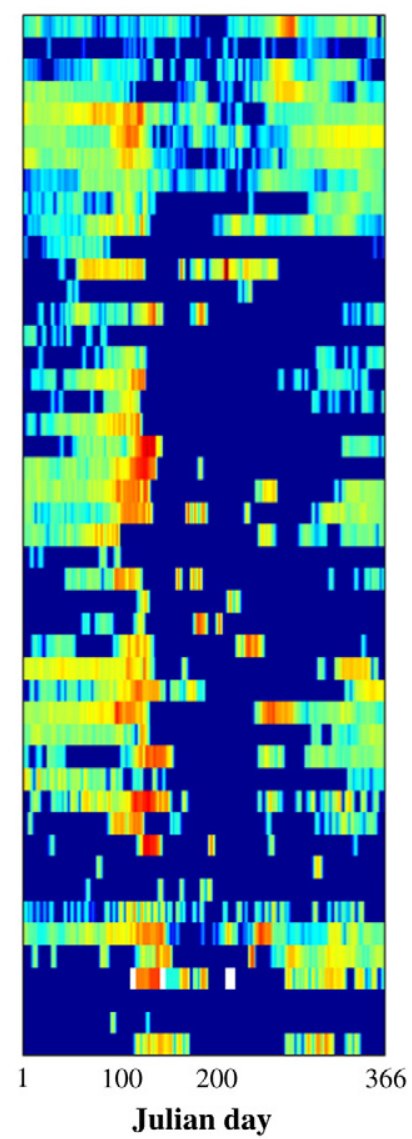

C) O. aurita

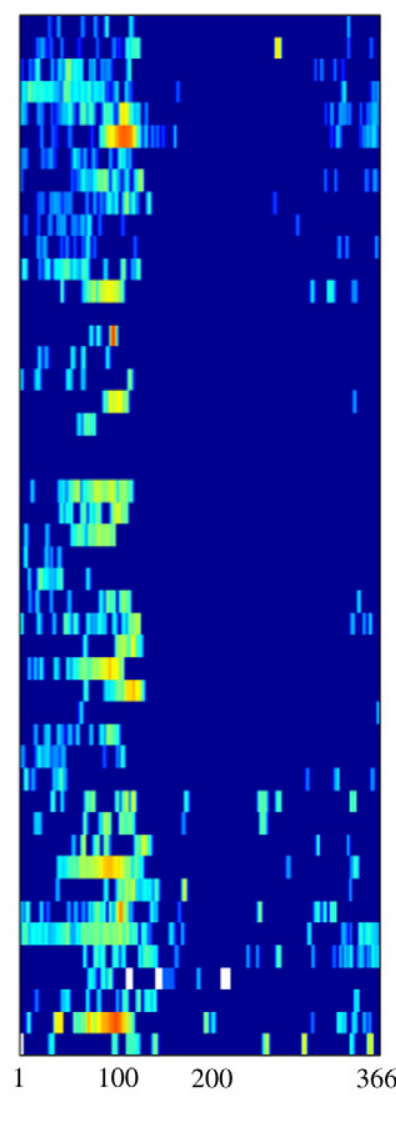




observation.

of $G$. delicatula was found $\left(R^{2}=14 \%, p=0.04\right)$ at the $5 \%$ significance level for a shorter time period from 1975 to 2005. No significant $(p=0.05)$ linear temporal trends were found in 0 . aurita's indices.

The winter occurrences of 0 . aurita appeared to be associated with lower than average Secchi disc values and higher than average biomass during autumn (Fig. 4) and did not appear to be affected by the grazer biomass of Acartia spp. The early spring occurrences of $G$. delicatula were instead associated with higher than average SST, lower than average abundance of Acartia spp. and higher than average initial biomass during winter (Fig. 4). Further, the later spring occurrences of $T$. nitzschioides were associated with lower than average Secchi disc depths, higher than average grazing biomass of Acartia spp. and lower than average initial biomass during autumn (Fig. 4). Lower than average Secchi disc depths delayed T. nitzschioides' and G. delicatula's bloom timings whereas 0 . aurita's SOGP was earlier. Higher than average sunshine duration was associated with a delayed G. delicatula bloom. In contrast to Secchi disc depth, grazing biomass of Acartia spp. and initial phytoplankton biomass and to some extent SST, sunshine duration had apparently no big influence on the start of the blooms (Fig. 4). The SOGP would therefore appear to be determined by a complex relation between Secchi disc depth, Acartia biomass and initial phytoplankton biomass (and to a lesser extent by SST).

The multiple regression analysis of the EOGP of the three diatoms suggested that the mean values of sunshine hours during growth duration could explain most of the variation observed in the EOGP of the three diatom species (see Table 1). Higher mean sunshine hours delayed T. nitzschioides' and O. aurita's EOGP. In contrast, G. delicatula's
EOGP was negatively correlated with sunshine duration and water transparency. Average SST during the bloom duration of G. delicatula and T. nitzschioides explained a remarkable part of the variability observed in their EOGP delaying their EOGP with warmer average SST. The magnitude of the mean grazing biomass during bloom duration was significantly correlated with $G$. delicatula and $O$. aurita. The positive correlation between silicate and G. delicatula's EOGP indicated a delay of EOGP with higher silicate concentrations and ammonium's positive correlation with T. nitzschioides' EOGP indicated a delay of its EOGP with higher ammonium concentrations.

\section{Discussion}

Previous studies focused on bulk biomass or chlorophyll when addressing biological responses to environmental variability (e.g. McQuatters-Gollop et al., 2007). The high frequency biotic and abiotic data of Helgoland Roads sampled over the last forty years allowed us to analyse the long-term responses of individual species particularly to seasonal changes in environmental conditions and grazing pressure in the marine pelagic system under climate warming. For the first time we have shown that diatoms with very different autoecological characteristics also show very different responses to grazers and environmental variables. Taking this variability into account may be important to manage ecosystem health.

In this study, the analysed diatoms G. delicatula, T. nitzschioides and $O$. aurita exhibited interannual variations in growth timings and dissimilar but regular cyclic annual abundance patterns during the time period from 1962 to 2008. It is rather unlikely that the same 
A) Guinardia delicatula

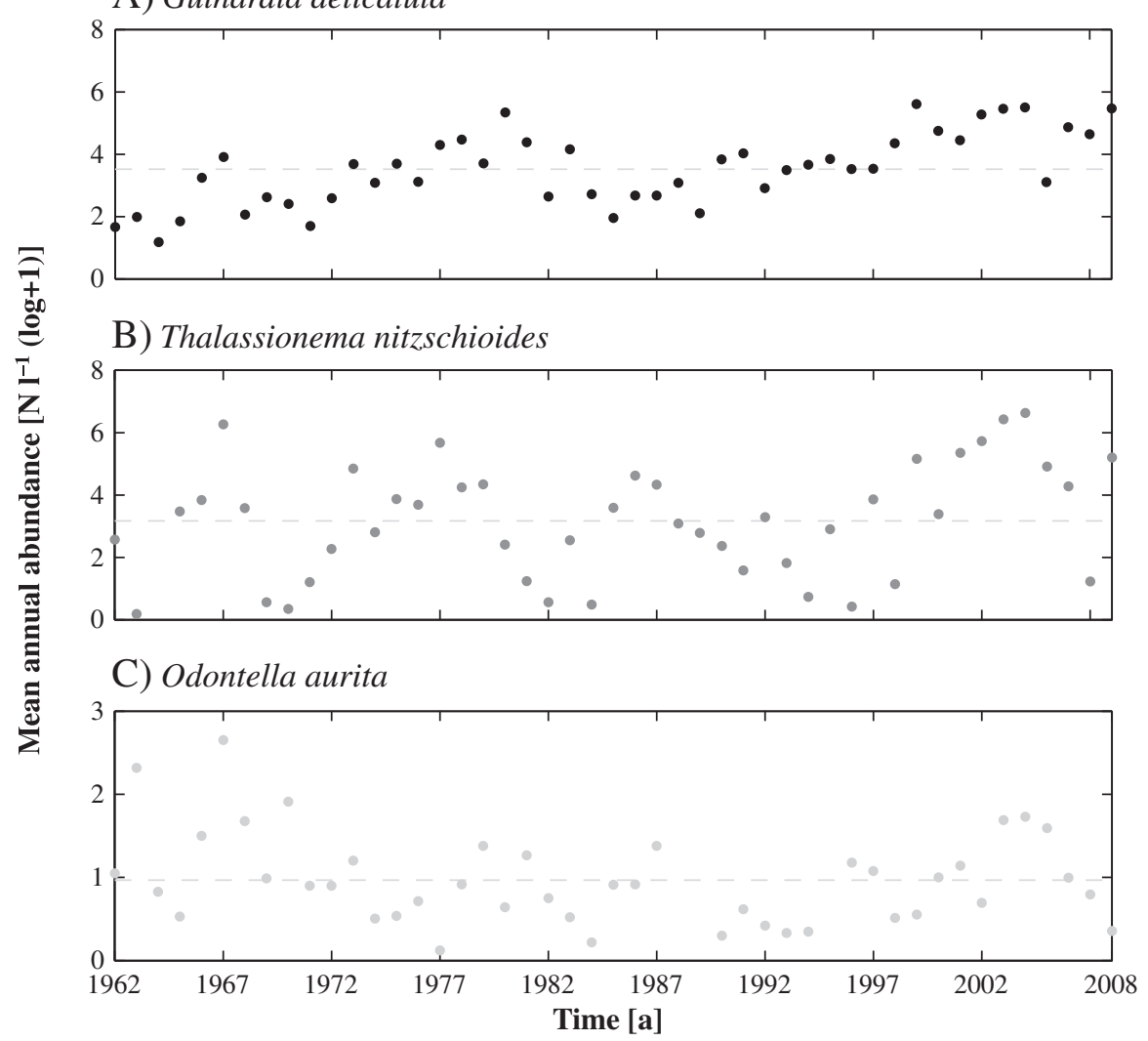

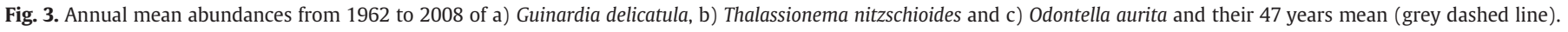

physical and grazing factors would determine most of the annual abundance patterns of all three diatoms as the frequencies of these diatom cycles were unequal. These dissimilar cycles must stem from different grazing, weather cycles or even potentially internal variations in their reproduction, life cycle (D'Alelio et al., 2001) or resting stages. Of the three diatoms, G. delicatula and T. nitzschioides showed significant trends towards earlier bloom timings for 1962-2008 and could be related to an increasing temperature trend. T. nitzschioides also showed a significant trend towards earlier timings of decline in abundance during that time period and a later decline of abundance for $G$. delicatula over time was found. A broadening of occurrence related to climate warming was found for another species Cylindrotheca closterium by Edwards and Richardson (2004). Only the biological temporal indices of 0 . aurita did not show a significant linear trend during this time period. This is remarkable as nutrient loads, hydrodynamic and meteorological conditions around Helgoland have all changed (Wiltshire et al., 2008). Especially the late seventies were characterized by changing silicate to nitrogen ratios and absolute nitrogen concentrations. There is ample evidence for an increase in nitrate inputs into coastal seas like the German Bight during this period, but not so for silicate (Radach et al., 1990; Wiltshire et al., 2010). A considerable shift seen in G. delicatula's bloom timings (see Figure S1.1 a in supplementary material) could however be attributed to a shift in the hydrodynamic environment around Helgoland during that time as demonstrated by Wiltshire et al. (2010). There is a clear need to investigate further the co-limitation effects between nutrients and light, and rates of biochemical processes that affect nutrient loadings as suggested by Philippart and Cadee (2000) and analyse the effects of internal variations.

Different explanatory variables corresponded to later, average, and earlier SOGP values of the three diatoms. G. delicatula showed a tendency towards earlier bloom timings if water temperatures were higher than average and if grazing biomass was lower than average.
A strong vertical mixing, as indicated by lower Secchi depths, played the most important role in earlier appearances of 0 . aurita. Higher turbulence in the water through vertical mixing (e.g. strong tidal movements, storms, precipitation, run-off) preceding the bloom expressed in low Secchi disc depths may seed the sea surface with 0 . aurita cells and favourable conditions in the surface water may then favour their growth. Lower water transparencies and higher grazing pressure, by contrast, delayed the bloom timings of $T$. nitzschioides. As copepod abundances showed considerable variation interannually (with a decline in recent years), these diatom species also showed corresponding variation in their SOGP between years. This result including the role of grazing still needs to be confirmed experimentally. The timing of occurrences of each diatom species was affected by the magnitude of their preceding biomass which resulted in earlier bloom timings with higher than average preceding diatom biomass and in later bloom timings with lower than average preceding diatom biomass. Therefore, the magnitude of the diatom biomass of the previous year resulting in an increased or decreased abundance of overwintering cells can be important in determining the next years' bloom timing. This finding highlights the importance to analyse the life cycle of these diatoms for resting stage formation. The differences in the factors responsible for the SOGP of the different species make it unlikely that warming would result in the same temporal change in the onset of bloom season of all the three diatoms and one, such as $G$. delicatula, could be favoured in the long run.

The results of the multiple linear regression analysis showed that the timings of the decline of the three diatoms were mainly correlated with decreasing nutrient concentration. Sunshine duration could prolong the duration of the bloom of $T$. nitzschioides and 0 . aurita provided that enough nutrients were available. In the case of $G$. delicatula, however, sunshine duration was negatively correlated with EOGP, suggesting the possibility that G. delicatula may be photoinhibited under higher light intensities/more sunshine hours in the 

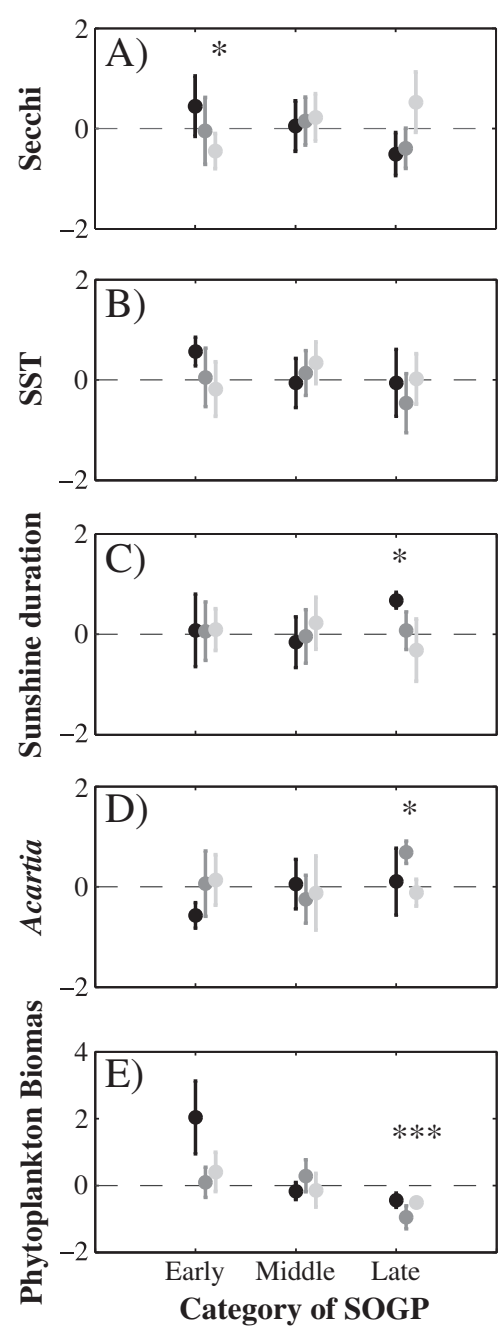

Fig. 4. Normalised Secchi disc depth, sea surface temperature, sunshine duration, Acartia abundance and phytoplankton biomass corresponding to early, middle and late start of the growth period of Guinardia delicatula (black), Thalassionema nitzschioides (grey) and Odontella aurita (light grey). The values of the explaining variables were averaged over autumn (September -December) for Thalassionema nitzschioides and Odontella aurita and winter (January -March) for Guinardia delicatula preceding the start of the bloom season. The three categories of early, middle and late start of the growth period correspond to values $>1$ above the deviation from the long-term mean value relative to $1975-2005$, to values \pm 1 around the deviation from the 1975 -2005 mean value and to values b1 below the deviation from the 1975 -2005 long-term mean value, respectively. Error bars denote one standard error of the mean. Asterisks indicate time periods during which the anomalies differ significantly from zero. The number of observations in the middle category is higher than the number of observations in the other two categories, resulting in a higher statistical power for this category.

shallow Helgoland waters. Another explanation could be that G. delicatula's photosynthesis and nutrient uptake rates may be enhanced with higher light intensities which may lead to earlier nutrient deficiencies (correlation coefficient between light and phosphate: $r=$ $-0.5, p=0.002)$. G. delicatula and T. nitzschioides showed later declines in abundance with warmer water temperatures possibly via e.g. accelerated growth rates (Harrison and Platt, 1980) as photosynthetic carbon assimilation is enzymatically controlled and a temperature-dependent process (Falkowski and Raven, 1997). Since 1998/99 autumn SST is warmer compared to the previous years (results not shown) which may explain G. delicatula's broadening of occurrence into autumn. The occurrence of such a phenomenon may result in an increased abundance of overwintering G. delicatula cells, and thus, may affect its bloom timing in the following. The identified
Table 1

Regression results for the EOGP. Range of significant predictors for the end of the growth period (EOGP) of G. delicatula, T. nitzschioides and 0 . aurita are listed and the model diagnostics.

\begin{tabular}{llrrrrr}
\hline$p_{?}<0.05$ & Significant & $\beta$ & $t$-stat & $F$ & $R^{2}$ & Adj. $R^{2}$ \\
& predictor & & & & & \\
\hline \multirow{2}{*}{ EOGP G. delicatula } & Acartia spp. & -0.56 & -5.1 & 14.8 & 0.75 & 0.69 \\
& Secchi disc depth & -0.32 & -2.8 & & & \\
& $\mathrm{SiO}_{4}$ & 0.24 & 2.15 & & & \\
& Sunshine duration & -0.66 & -5.67 & & & \\
& $\mathrm{SST}$ & 0.65 & 5.99 & & & \\
EOGP T. nitzschioides & $\mathrm{NH}_{4}$ & 0.31 & 2.1 & 8.34 & 0.48 & 0.40 \\
& Sunshine duration & 0.41 & 2.5 & & & \\
& SST & 0.43 & 2.5 & & & \\
EOGP 0. aurita & Sunshine duration & 0.71 & 4.92 & 12.25 & 0.47 & 0.41 \\
& Temora longicornis & -0.29 & -2.02 & & & \\
\hline
\end{tabular}

differences in the variables affecting the three diatom species imply that changes in the responsible factors might influence the species assemblage and interaction.

Previous studies concerning biological responses to global warming or periodic climate variability focused on bulk biomass or chlorophyll, while neglecting species biotic interactions (e.g. Edwards et al., 2001 and Wiltshire et al., 2008). Wiltshire et al. (2008) postulated that increased grazing pressure might be the reason of a shift in biomass observed at Helgoland Roads. In this work, the identified responses at the species level showed that grazing pressure was one of the major factors influencing the seasonality of all three diatoms. A higher grazing biomass delayed the diatoms' first occurrence or advanced their EOGP. Grazing was found to be important also in the fresh water ecosystem of Lake Constance in delaying the seasonal succession (Gaedke et al., 2009).

Even with the inherent limitations of the Helgoland Roads data due to hydrodynamic conditions as described by Hickel (1998) and Radach (1998) and others it was possible to characterise potential long-term trends in occurrence of the three diatoms and to determine the variables associated with those trends. The SOGP is not a qualitative estimate like the date of the first exponential growth rate (see Wiltshire et al., 2008), but a quantitative one which captures the mean features of the seasonality of the three diatoms and could be compared to ecosystem models which do not resolve the growth phase explicitly. These temporal indices provide a tool which allows comparative examination of the same species from different time series and thus the ecology of species over large geographic scales can be examined. Therefore the scope of our analyses goes far beyond the situation at Helgoland Roads. More experimental work and analyses, as well as modelling are needed to strengthen our findings.

The co-occurrence of the dominant diatoms G. delicatula, T. nitzschioides and 0 . aurita at Helgoland Roads was observed over decades and a widening of the time period of occurrence of $G$. delicatula was also recognised (Wiltshire et al., 2010). Since the studied diatoms are widespread in the North Sea the observed responses are also applicable to other systems, not just the particular conditions at Helgoland Roads. This study attributes the identified changes of occurrence of the three diatoms to their differential response to grazers and environmental variables. Such differential response, followed by changes in appearance may result in an over-representation of one species over the other, affect competitive relationships and may ultimately alter ecological processes such as nutrient cycles or energy flow throughout different ecosystem compartments. These species specific differences in sensitivity to forcing variables shown in the present study could lead to shifts in community structure at the present climate warming and could ultimately have wider implications to the overall ecosystem health of the North Sea, re-emphasising the need for further species specific analyses, rather than studies of bulk parameters. 


\section{Acknowledgements}

Many thanks to the crews of the research vessels "Aade" and "Ellenbogen", of the Biologische Anstalt Helgoland, for their unfailing provision of samples, and to I. Nast, P. Mangelsdorf, K. Treutner, S. Peters and K. Carstens for counting and measuring over 45 years. Thanks are due to Agostino Merico and Sönke Hohn for useful comments on the manuscript.

\section{Appendix A. Supplementary data}

Supplementary data to this article can be found online at doi:10. 1016/j.seares.2011.11.001.

\section{References}

Baars, J.W.M., 1979. Autoecological investigations on marine diatoms 1: experimenta results in biogeographical studies. Hydrobiological Bulletin 13, 123-137.

Beaugrand, G., Brander, K., Lindley, A., Souissi, S., Reid, P.C., 2003. Plankton effect on cod recruitment in the North Sea. Nature 426, 661-664.

Beninca, E., Huisman, J., Heerkloss, R., Jöhnk, K.D., Branco, P., Van Nes, E.H., Scheffer, M., Ellner, S.P., 2008. Chaos in a long-term experiment with a plankton community. Nature 451, 822-825.

Brzezinski, M.A., 2004. The Si:C:N ratio of marine diatoms: interspecific variability and the effect of some environmental variables. Journal of Phycology 21 (3), 347-357.

Cleland, E.E., Chuine, I., Menzel, A., Mooney, H.A., Schwartz, M.D., 2007. Shifting plant phenology in response to global change. Trends in Ecology \& Evolution 22 (7), 357-365.

Colijn, F., Cadee, G.C., 2003. Is phytoplankton growth in the Wadden Sea light or nitrogen limited? Journal of Sea Research 49, 83-93.

Cushing, D.H., 1990. Plankton production and year-class strength in fish populations: an update of the match/mismatch hypothesis. Advances in Marine Biology 26, $1-122$.

Cushing, D.H., 1995. The long-term relationship between zooplankton and fish. ICES Journal of Marine Science 52, 611-626.

D'Alelio, D., d'Alcala, M.R., Dubroca, L., Sarno, D., Zingone, A., Montresor, M., 2001. The time for sex: a biennial life cycle in a marine planktonic diatom. Limnology and Oceanography 55 (1), 106-114.

Drebes, G., 1974. Marine Phytoplankton, eine Auswahl der Helgoländer Planktonalgen (Diatomeen, Peridineen). Georg Thieme Verlag, Stuttgart.

Edwards, M.A., Richardson, A.J., 2004. Impact of climate change on marine pelagic phenology and trophic mismatch. Nature 430, 881-884.

Edwards, M., Reid, P.C., Planque, B., 2001. Long-term and regional variability of phytoplankton biomass in the Northeast Atlantic (1960-1995). ICES Journal of Marine Science 58, 39-49.

Falkowski, P.G., Raven, J.A., 1997. Aquatic Photosynthesis. Blackwell Science, Massachusetts US. 375 pp.

Franke, H.-D., Buchholz, F., Wiltshire, K.H., 2004. Ecological long-term research at Helgoland (German Bight, North Sea): retrospect and prospect-an introduction. Helgoland Marine Research 58, 223-229. doi:10.1007/s10152-004-0197-s.

Gaedke, U., Ruhenstroth-Bauer, M., Wiegand, I., Tirok, K., Aberle, N., Breithaupt, P., Lengfellner, K., Wohlers, J., Sommer, U., 2009. Biotic interactions may overrule direct climate effects on spring phytoplankton dynamics. Global Change Biology 2009. doi:10.1111/j.1365-2486.2009.02009.x.

Gowen, R.J., McCullough, G., Kleppel, G.S., Houchin, L., Elliott, P., 1999. Are copepods important grazers of the spring phytoplankton bloom in the western Irish Sea? Journal of Plankton Research 21, 465-483.

Greve, W., Reiners, F., Nast, J., Hoffmann, S., 2004. Helgoland Roads time-series mesoand macrozooplankton 1975 to 2004: lessons from 30 years of single spot high frequency sampling at the only off-shore island of the North Sea. Helgoland Marine Research 58, 274-288.

Greve, W., Prinage, S., Zidowitz, H., Nast, J., Reiners, F., 2005. On the phenology of North Sea ichthyoplankton. ICES Journal of Marine Science 62, 1216-1223.

Harrison, W.G., Platt, T. 1980. Variations in assimilation number of coastal marine phytoplankton: effects of environmental co-variates. Journal of Plankton Research 2, 249-260.

Hays, G.C., Richardson, A.J., Robinson, C., 2005. Climate change and marine plankton. Trends in Ecology \& Evolution 20, 337-344.

Hendey, N.I., 1964. An introductory account of the smaller algae of British coastal waters. 5. Bacillariophyceae (Diatoms). Fisheries Investigation Series 4, London.

Hickel, W., 1998. Temporal variability of micro- and nanoplankton in the German Bight. ICES Journal of Marine Science 55, 600-609.
IPCC, 2007. Climate change 2007, the Fourth Assessment Report (AR4).

Jassby, A.D., Powell, T.M., Goldman, C.R., 1990. Interannual fluctuations in primary production: direct physical effects and trophic cascade at Castle Lake, California. Limnology and Oceanography 35, 1021-1038.

Karentz, D., Smayda, TJ., 1984. Temperature and seasonal occurrence patterns of 30 dominant phytoplankton species in Narragansett Bay over a 22-year period (1959-1980). Marine Ecology Progress Series 18, 277-293.

Litchman, E., Klausmeier, C.A., 2008. Trait-based community ecology of phytoplankton. Annual Review of Ecology, Evolution, and Systematics 39, 615-639.

Loebl, M., Colijn, F., van Beusekom, J.E.E., Baretta-Bekker, J.G., Lancelot, C., Philippart, C.J.M., Rousseau, V., Wiltshire, K.H., 2009. Recent patterns in potential phytoplankton limitation along the Northwest European continental coast. Journal of Sea Research 61, 34-43.

McQuatters-Gollop, A., Raitsos, D.E., Edwards, M., Pradhan, Y., Mee, L.D., Lavender, S.J., Attrill, M.J., 2007. A long-term chlorophyll data set reveals regime shift in North Sea phytoplankton biomass unconnected to nutrient trends. Limnology and Oceanography 52 (2), 635-648.

Möllmann, C., Kornilovs, G., Sidrevics, L., 2000. Long-term dynamics of main mesozooplankton species in the central Baltic Sea. Journal of Plankton Research 22, 2015-2038.

Müller-Navarra, D.C., Güss, S., Storch, H. von, 1997. Interannual variability of seasonal succession events in a temperate lake and its relation to temperature variability. Global Change Biology 3, 429-438.

Philippart, C.J., Cadee, G.C., 2000. Was total primary production in the western Wadden Sea stimulated by nitrogen loading? Helgoland Marine Research 54, 55-62.

Raabe, T., Wiltshire, K.H., 2008. Quality control and analyses of the long-term nutrient data from Helgoland Roads, North Sea. Journal of Sea Research 61, 3-16.

Radach, G., 1998. Quantification of long-term changes in the German Bight using an ecological development index. ICES Journal of Marine Science 55, 587-599.

Radach, G., Berg, J., Hagmeier, E., 1990. Long-term changes of the annual cycles of meteorological, hydrographic, nutrient and phytoplankton time series at Helgoland and at LV ELBE 1 in the German Bight. Continental Shelf Research 10 (4), 305-328. doi:10.1016/0278-4343(90)90054-P.

Reynolds, C.S., 1989. Physical Determinants of Phytoplankton Succession. In: Sommer, U. (Ed.), Plankton Ecol. Springer-Verlag, Berlin, pp. 9-56.

Reynolds, C.S., 2006. Ecology of Phytoplankton. University Press, Cambridge.

Rousseau, V., Leynaert, A., Daoud, N., Lancelot, C., 2002. Diatom succession, silicification and silicic acid availability in Belgian coastal waters (Southern North Sea). Marine Ecology Progress Series 236, 61-73.

Schlüter, M.H., Merico, A., Wiltshire, K.H., Greve, W., 2008. A statistical analysis of climate variability and ecosystem response in the German Bight. Ocean Dynamics 58 (3-4), 169-186.

Schlüter, M.H., Merico, A., Wiltshire, K.H., Boersma, M., Greve, W., 2010. Phenological shifts of three interacting zooplankton groups in relation to climate change. Global Change Biology 16 (11), 3144-3153. doi:10.1111/j.1365-2486.2010.02246.x.

Schrum, C., 2010. Thermohaline stratification and instabilities at tidal mixing fronts: results of an eddy resolving model for the German Bight. Continental Shelf Research 17 (6), 689-716.

Schwaderer AS (2006) Missing links-experimental evaluation of phytoplankton growth and succession. Dissertation, University of Kiel, 2006.

Sommer, U., 1989. The role of competition for resources in phytoplankton succession. In: Sommer, U. (Ed.), Plankton Ecology. Springer-Verlag, Berlin, pp. 57-106.

Sommer, U., Gliwicz, Z.M., Lampert, W., Duncan, A., 1986. The PEG-model of seasonal succession of planktonic events in fresh waters. Archiv für Hydrobiologie 106, 433-471.

Thuiller, W., 2007. Climate change and the ecologist. Nature 448, 550-552.

Tiffany, M.A. Lange, C.B., 2002. Diatoms provide attachment sites for other diatoms: a natural history of epiphytism form southern California. Phycology 41 (2), 116-124.

Walther, G.-R., Post, E., Convey, P., Menzel, A., Parmesan, C., Beebee, T.J.C., Fromentin, J.M., Hoegh-Guldberg, O., Bairlein, F., 2002. Ecological responses to recent climate change. Nature 416, 389-395. doi:10.1038/416389a.

Wiltshire, K.H., Dürselen, C.D., 2004. Revision and quality analyses of the Helgoland Reede long-term phytoplankton data archive. Helgoland Marine Research 58, 252.

Wiltshire, K.H., Manly, B.F.J., 2004. The warming trend at Helgoland Roads, North Seas: phytoplankton response. Helgoland Marine Research 58, 269-273.

Wiltshire, K.H., Malzahn, A.M., Wirtz, K., Greve, W., Janisch, S., Mangelsdorf, P., Manly, B.F.J., Boersma, M., 2008. Resilience of North Sea phytoplankton spring bloom dynamics: an analysis of long-term data Helgoland Roads. Limnology and Oceanography 53 (4), 1294-1302.

Wiltshire, K.H., Kraberg, A., Bartsch, I., Boersma, M., Franke, H.D., Freund, J., Gebühr, C., Gerdts, G., Stockmann, K., Wickels, A., 2010. Helgoland roads: 45 years of change. Estuaries and Coasts 33, 295-310. doi:10.1007/s12237-009-9228-y.

Wirtz, K., Wiltshire, K.H., 2005. Long-term shifts in marine ecosystem functioning detected by inverse modeling of the Helgoland Roads time-series. Journal of Marine Systems 56, 262-282. 